\title{
Determination of Lithium Ion Battery Characteristics for Hybrid Vehicle Models
}

\author{
Tolga Kocakulak ${ }^{1 *}$, Hamit Solmaz ${ }^{2}$ \\ 0000-0002-1269-6370', 0000-0003-0689-6824² \\ ${ }^{I}$ Electricity and Energy Department, Vocational High School of Technical Sciences, Burdur Mehmet Akif Ersoy University, Burdur, \\ 15100,Turkey \\ ${ }^{2}$ Automotive Engineering Department, Faculty of Technology, Gazi University, Ankara, 06500, Turkey
}

\begin{abstract}
In this study, the characteristic properties of a lithium ion battery cell which is in the dimension standard of " 18650 ", creates the battery pack of a hybrid vehicle are determined. The test setup that is able to measure instantaneous current, open circuit voltage and circuit voltage of the battery cell during charging and discharging is prepared. The battery cell is periodically subjected to charge and discharge processes on the test setup and current, battery voltage and open circuit voltage values are obtained. Based on the results of the test, internal resistance and efficiency values are calculated depending on status of the battery charge ratio by using "Equivalent circuit" and "Rint method". With the test results obtained, efficiency values were calculated depending on the battery charge rate during the charge and discharge process of the battery. Internal resistance and efficiency graphs of the battery cell are created based on the status of the battery charge ratio after the result of the process performed during the charging and discharging. It is determined that if the battery cell charge level is between $15 \%$ to $\% 95$, the average internal resistance value is $51,452 \mathrm{mOhm}$ during discharhing and $57,48 \mathrm{mOhm}$ during charging. It is also determined that if the battery cell charge level is between $15 \%$ to $\% 95$, the average efficiency is $98,58 \%$ during discharhing $(1 \mathrm{~A})$ and $98,496 \%$ during charging (1A).
\end{abstract}

Keywords: Lithium battery, Internal resistance, Efficiency, Modeling, Equivalent circuit method

\section{* Corresponding author \\ Tolga Kocakulak \\ tkocakulak@mehmetakif.edu.tr}

Adress: Electricity and Energy Department, Vocational high school of technical sciences, Burdur Mehmet Akif Ersoy University,Burdur,15100,Turkey

Tel :+90 2482134555

Fax: +902482134598

Research Article

Manuscript

Received $\quad 19.04 .2020$

Revised 21.08.2020

Accepted $\quad 10.10 .2020$

Doi: 10.30939/ijastech..723043

\section{Introduction}

Battery is a device that stores electrical energy as chemical energy and converts chemical energy into electrical energy when a load is connected. In hybrid and electric vehicle technology, high voltage battery packs are used to supply electric energy for electric drive and auxiliary devices. Battery packs are formed by serial and parallel connection of many battery cells [1]. A single battery cell consists of a positive and negative electrode, electrolyte and a separator which is used to separate the electrodes from each other [2,3].There are some parameters should be considered in the selection of batteries used in hybrid and electric vehicles. These parameters are as follows $[4,5,6,7]$ :
- Mass and volumetric power density

- Initial purchase \& lifetime cost

- Life cycle cost and operating time

- Safety

- Charge and discharge efficiency

Nowadays, there are many types of batteries which have different chemical and physical structures to be used in hybrid and electric vehicles. In addition, battery technology is improving day by day. Batteries directly determine the vehicle range in electric vehicles and have an important role in decreasing the fuel consumption in hybrid vehicles $[8,9]$. In 
Table 1, properties of some battery types which in the development progress and are in use on hybrid vehicles can be seen.

Table 1. Batteries used in hybrid and electric vehicles and their characteristic features [10]

\begin{tabular}{c|c|c|c|c|c}
$\begin{array}{c}\text { Battery } \\
\text { type }\end{array}$ & $\begin{array}{c}\text { Operating } \\
\text { temp. }\left(\mathrm{C}^{\circ}\right)\end{array}$ & $\begin{array}{c}\text { Efficiency } \\
(\%)\end{array}$ & $\begin{array}{c}\text { Density } \\
(\mathrm{Wh} / \mathrm{kg})\end{array}$ & $\begin{array}{c}\text { Voltage } \\
(\mathrm{V})\end{array}$ & $\begin{array}{c}\text { Life } \\
\text { cycle }\end{array}$ \\
\hline $\begin{array}{c}\text { Lead- } \\
\text { acid }\end{array}$ & $-30-60$ & 85 & $20-40$ & 2,1 & 200 \\
\hline NiMH & $-20-50$ & 80 & $40-60$ & 1,2 & $<2500$ \\
\hline Li-ion & -2055 & 93 & $100-200$ & 3,6 & $<2500$
\end{tabular}

Lead acid batteries are used in power systems in many sectors for more than a century. Its cost-efficiency, high discharge current, maintainability are among the most important advantages of this battery type. However, there are some disadvantages such as low cycle life and low energy density compared to other battery packs [4].

Even though nickel cadmium batteries is an alternative storage source in daily usage thanks to their advantages such as higher energy density, long cycle life and low maintenance costs compared to lead acid batteries, they are that common. NiMH batteries are developed to decrease nickel cadmium batteries' disadvantages. NiMH batteries have higher power density even though there is no change in nominal voltage values. Safety problems may occur when NiMH batteries are overcharged $[11,12,13]$.

The most common battery type used in hybrid and electric vehicle is lithium ion batteries. Lithium batteries were commercially produced in the 1990s and their use became rapidly widespread. Lithium ion batteries have high storage energy efficiency and higher energy density compared to other battery technologies [14]. Lithium ion batteries have approximately 110-160 Wh/kg energy density. Many studies are being carried out to improve the chemical structure of lithium batteries and to increase its safety and energy density. These studies are especially focused on the development of alternative materials and cost reduction for the electrode construction of lithium ion batteries $[4,15]$.

Lithium polymer batteries have approximately lithium ion batteries properties. The only difference between these two battery structures is using of polymer material as the electrolyte. Polymer electrolyte material has higher conductivity than other organic liquid electrolytes [8]. Lithium iron phosphate batteries are lithium batteries that their positive electrode material is lithium iron phosphate. Lithium iron phosphate batteries are widely used due to the high energy density, life cycle and safety. Besides these advantages, its performance is slightly lower than other lithium-ion batteries. In lithium sulfide (Li-S) batteries, sulfur is used as the cathode material. Lithium sulfide batteries are lithium-based batteries with high energy density, high charging efficiency, low cell voltage and an average cycle life [11]. Characteristic of lithium based battery types are shown on Table 2 .

Table 2. Lithium battery types used in hybrid and electric vehicles and their characteristics $[10,16]$

\begin{tabular}{|c|c|c|c|c|c|}
\hline Initials & $\mathrm{LCO}$ & NLO & LMO & LFP & LTO \\
\hline Battery type & $\begin{array}{c}\text { Lithium Cobalt } \\
\text { Oxide }\end{array}$ & $\begin{array}{c}\text { Lithium Nickel } \\
\text { Oxide }\end{array}$ & $\begin{array}{c}\text { Lithium Manganese } \\
\text { Oxide }\end{array}$ & $\begin{array}{c}\text { Lithium Iron } \\
\text { Phosphate }\end{array}$ & $\begin{array}{c}\text { Lithium Tita- } \\
\text { nate }\end{array}$ \\
\hline Positive electrode & $\mathrm{LiCoO}_{2}$ & $\mathrm{LiNiO}_{2}$ & $\mathrm{LiMn}_{2} \mathrm{O}_{4}$ & $\mathrm{LiFePO}_{4}$ & LMO, NCA \\
\hline Cell voltage (V) & $3,7-3,9$ & 3,6 & 4 & 3,3 & $2,3-2,5$ \\
\hline Energy density $(\mathrm{Wh} / \mathrm{kg})$ & 150 & 150 & 120 & 130 & 85 \\
\hline Power & + & 0 & + & + & ++ \\
\hline Safety & - & 0 & + & + & ++ \\
\hline Life cycle & - & 0 & 0 & + & +++ \\
\hline
\end{tabular}

Another point to be mentioned about the batteries used in electric and hybrid vehicles is the control of the battery temperature. The purpose of battery cooling system is to keep the battery in the optimum temperature range necessary for it to operate in high efficiency and safe. Two basic battery temperature control systems, air and liquid cooling and heating, are widely used in electric and hybrid vehicles. Liquid and air-cooled systems are examined in two different groups: active and passive. The most effective cooling in batteries is provided by liquid and active cooling system $[17,18,19]$.

Ceylan M. et al, created a hybrid battery model and proved the accuracy of the model with measurements made in the laboratory environment. As the battery cell, they used lithium-ion battery cell with high energy density and long life cycle. They created the model of the battery using the equivalent circuit Thevenin method. While an average of $0.422 \%$ error was observed between simulation outputs and experiment results, a maximum of $3 \%$ error was obtained. This study proves that the battery model created using the equivalent circuit method is very close to reality [20]. Tremblay $O$. et al, created a battery model for use on dynamic simulation software. The variable parameter of the battery model has only been determined as the battery charge rate. They determined the variable parameter of the battery model only as the battery charge rate. The 
internal resistance graphic depending on the battery charge rate is taken from the manufacturer. Using mathematical equations, they calculated the battery efficiency based on battery charge rate. In this model which is created for nickel metal hidirite battery cell, they obtained the average battery cell efficiency as $99.5 \%$. By creating models of different types of battery cells, they obtained battery cell voltages depending on time. They validated the model by comparing the results with manufacturer's data. They provided the verified battery model to be used on a hybrid vehicle model [21]. Samadani E. et al, created the lithium ion battery pack model and also performed the characterization test. The battery pack was created with 20 serial connections of the $\mathrm{LiFeMnPO}_{4}$ battery cell. The created battery pack model was subjected to different tests by using it on a Ford Escape vehicle. Open circuit voltage graphs based on the battery model and test process and the battery charge ratio were compared and they found that the difference between the values obtained was acceptable. In the internal resistance graph depending on the battery charge rate, it was found that it works most efficiently when the charge rate is between $10 \%$ and $90 \%$. They obtained that the battery internal resistance values were close to 210 $\mathrm{mOhm}$ as the battery charge rate was approaching to $0 \%$ and to $100 \%$. They found that the lowest resistance is 60 $\mathrm{mOhm}$ at the level where the battery charge rate is $55 \%$ [22].

In this study, the testing process of the battery cell is carried out in order to determine the characteristics of the battery cell to be used in the modeling of the lithium-ion battery pack. In order to create the best simulation of a battery pack, it is necessary to know some characteristic properties of the battery cell. In the design of the battery pack to be used on the hybrid vehicle, a 18650 size lithium ion battery cell is used. This battery cell allows minimum $5 \mathrm{~A}$ discharge and $1.62 \mathrm{~A}$ charge currents and is suitable for use on hybrid and electric vehicles. In addition, this battery cell has features (high energy density, high safety, etc.) that will allow it to be used on electric and hybrid vehicles. Battery cell manufacturers give the average internal resistance value of the battery cell in the catalogs. However, since factors such as ambient temperature, battery charge life cycle constantly change the internal resistance of the battery, the datasheet and catalogs cannot share the internal resistance graph based on the battery charge rate. In this study, a battery test setup is created. During the charging and discharging of the battery cell, open circuit voltage, internal resistance and efficiency graphs based on the SOC are obtained. In case the battery cell is charged and discharged with a current of $1 \mathrm{~A}$, the efficiency values of the battery cell depending on the battery charge rate are obtained.

\section{Material and method}

Batteries are used on hybrid and electric vehicles to provide electric power to the electric motor and accessories. There are many types of batteries vary on their technical properties, voltage changes, operating temperatures and modeling method. The battery charge status must be known in order to observe the charge status of the battery and to control the hybrid system according to the charge status [21].

A battery model is created to determine the battery characteristics of the batteries. There are four common methods for battery modelling. These methods are analytical (experimental), statistical, electrochemical (physical) and electrical circuit models [23].

Analytical model is combination of physical and statistical model. The physical model is created with the values obtained with the help of experiments [20]. The statistical model is based on creating meaningful structures from information rather than deriving parameters with physical data or mathematical models. This modeling method is easy and fast, but its level of accuracy is low compared to other methods. This modeling method is not very preferred due to the low level of accuracy [11]. Electrochemical circuit models are one modeling type based on the chemical structure of the battery. This model is the best sensitive type of modeling but its structure is complex and difficult. It is not very preferred due to difficulty of application [20].

The electrical circuit model is created on equivalent circuits. The battery model created with equivalent circuits also allows mathematical operations to increase the accuracy of the battery model [11]. Power systems used on the vehicle tend to be gotten feed from the battery without losing any power. By creating a battery circuit model, battery operating time, charge status estimation and optimization can be easily resolved. Electrical circuit models are created by using the parameter values of the battery and circuit elements $[24,25]$. These parameters can be obtained experimentally and can be used with theoretical values. Many equivalent circuit models are used in the electrical circuit model and these models can be seen in Figure 1.

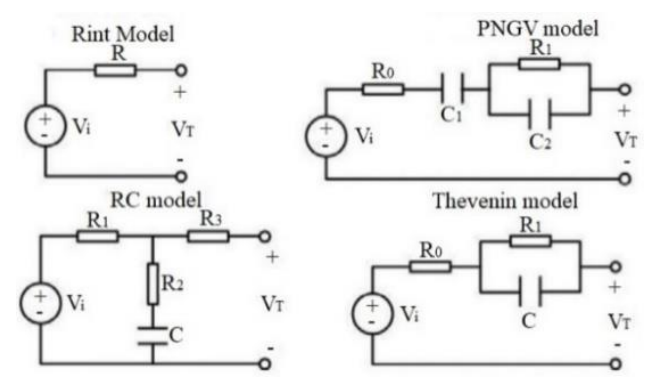

Fig. 1. Equivalent circuit models [11]

The equivalent circuit method is divided into four groups as Rint, PNGV, RC and Thevenin models. In the 
battery model created in this study, equivalent circuit Rint method is used.

\subsection{Equivalent circuit Rint method}

In this study, the battery cell model is created with the equivalent circuit method, the Rint circuit method. Figure 2 shows the Rint circuit diagram of the battery cell model.

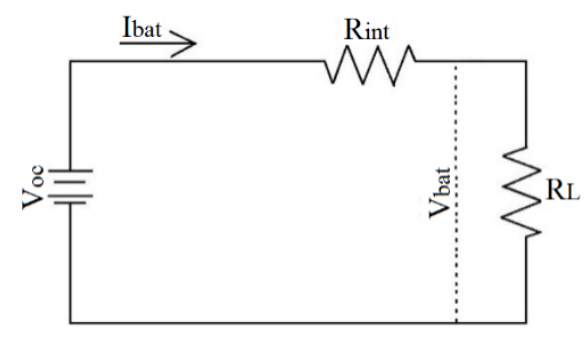

Fig. 2. Rint battery circuit diagram

In the process of using electric motor and high voltage receivers working on the hybrid electric vehicle, energy is supplied from the battery. $\mathrm{P}_{\text {bat }}$ shows the power that receivers tend to use from the battery and the SOC (Battery charge status) indicates the battery's charge rate.

In order to calculate the battery charge status, the current used from the battery $\left(\mathrm{I}_{\mathrm{bat}}\right)$ must be calculated. The effect of battery temperature on battery internal resistance is also evaluated. Battery charge status and battery efficiency are taken as output from the battery model. The parameters, the input and output of which are provided in the battery model, are shown in Figure 3.

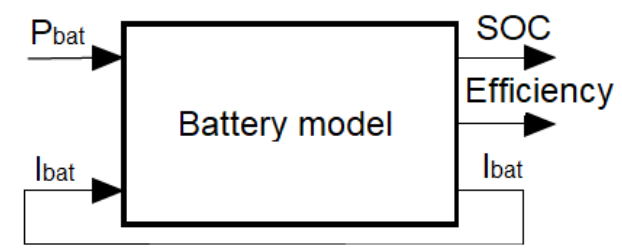

Fig. 3. Battery model input and output parameters

In order to calculate battery SOC and efficiency values, mathematical equations of battery Rint circuit model are used [26].

$$
R_{\text {internal }}=\left\{\begin{array}{lll}
I_{b a t}<0 & \text { ise } & R_{\text {charge }}(S O C) \\
I_{b a t}>0 & \text { ise } & R_{\text {discharge }}(S O C)
\end{array}\right\}
$$

The current value of the battery cell is considered negative during the charging period, and the current value is considered positive during the discharge process. Accord- ing to equivalent circuit method, Rint method, the relationship between battery voltage, battery open circuit voltage, current and internal resistance is stated as follows:

$$
V_{b a t}=V_{o c}(S O C)+I_{b a t} R_{\text {internal }}
$$

The relationship between the power used from the battery, battery voltage and current is stated as follows:

$$
I_{b a t}=\frac{P_{b a t}}{V_{b a t}}
$$

Change of battery charge rate (SOC) over time is stated as follows:

$$
\triangle S O C=\frac{\int_{t_{0}}^{t} V_{b a t} I_{b a t} d t}{B a t_{T o t E n}}
$$

And the battery SOC can be formulated as follows:

$$
S O C=S O C_{i}+\triangle S O C
$$

$\mathrm{R}_{\text {internal }}$ used in equations defines the internal resistance of the battery, $R_{\text {charge }}$ defines the internal resistance of the battery during charging, $\mathrm{R}_{\text {discharge }}$ defines the internal resistance of the battery during the discharge.

Battery efficiency is an important part of the energy efficiency of hybrid and electric vehicles. It is possible to calculate battery efficiency with a set of mathematical equation. During the charging and discharging, the internal resistances depending on the battery SOC should be known. The battery efficiency equation is derived by calculating the power loss caused by the internal resistance. The equation used to calculate battery efficiency is given in Equation 6 [27].

$$
\eta_{b a t}=\left\{\begin{array}{l}
I_{b a t}<0 \text { ise } \frac{V_{o c} I_{b a t}}{V_{o c} I_{b a t}-I_{b a t}^{2} R_{i c}} \\
I_{b a t}>0 \text { ise } \frac{V_{o c} I_{b a t}}{V_{o c} I_{b a t}+I_{b a t}^{2} R_{i c}}
\end{array}\right\}
$$

\subsection{Test setup}

The schematic representation of the test setup prepared for the battery cell test is shown in Figure 4. In the test scenario, the battery cell is charged / discharged for a certain amount of time, and data output is provided for the cases where the circuit is closed and opened at 30 second periods.

In the test setup, this process is enabled by the relay controlled by the Arduino mega. In the case of a charge test, the charger is taken to the system by means of a key. In the discharge test process, resistance is included into the circuit. 
The current value is measured by connecting the ammeter to the circuit in series, and the system and battery voltage are measured by connecting the voltmeter in parallel to the circuit.
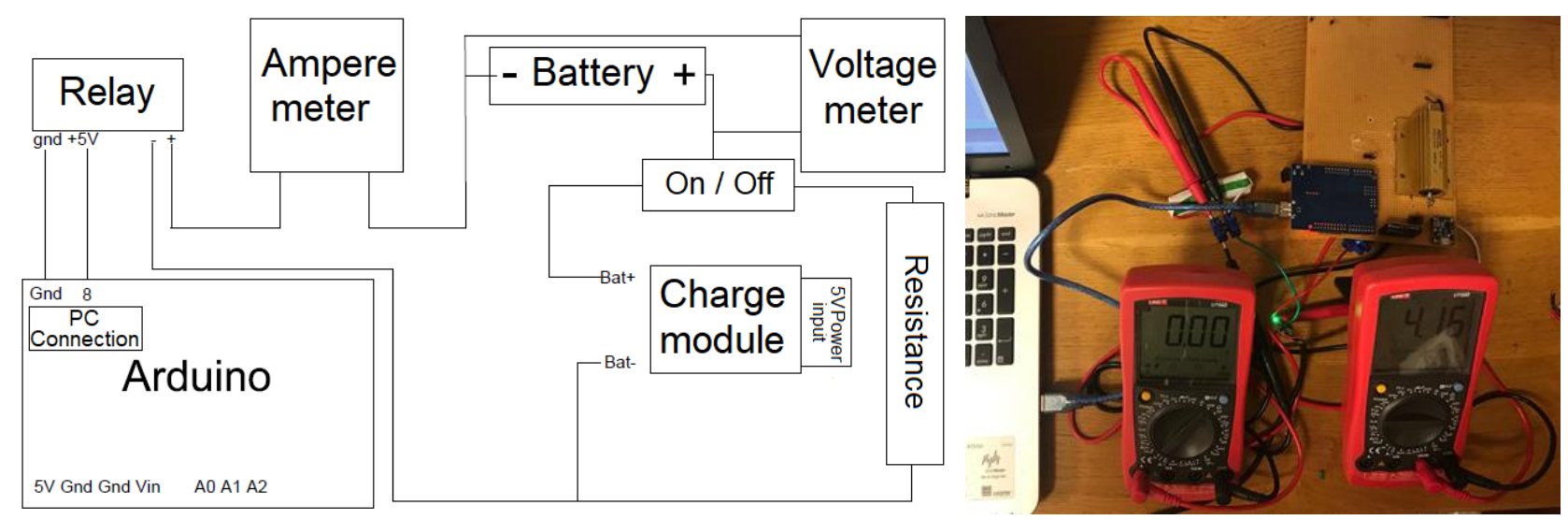

Fig.4. Schematic representation and prototype of the battery cell test setup

The devices and equipment in Table 3 are the materials used in the preparation of the setup for testing the battery.

Table 3. Properties of test materials

\begin{tabular}{c|c} 
Material & Description \\
\hline Battery cell & 18650 \\
\hline Relay & Finder 5 V (maximum 250 A) \\
\hline Resistance & ARCOL 2,2 Ohm 100 W \\
\hline Controller & Arduino Mega \\
\hline Measuring Device & UNI-T UT58D \\
\hline Charging device & TP4056 \\
\hline Cable & AWG 6 Standard \\
\hline Cooler & 12 V fan
\end{tabular}

Characteristic properties of the battery cell that is used in the test are shown in Table 4.

Table 4. Characteristic properties of the battery cell [28]

\begin{tabular}{c|c|c|c}
$\begin{array}{c}\text { Nominal } \\
\text { capacity } \\
(\mathrm{mAh})\end{array}$ & $\begin{array}{c}\text { Nominal } \\
\text { Voltage } \\
(\mathrm{V})\end{array}$ & $\begin{array}{c}\text { Min/Max. } \\
\text { Voltage } \\
(\mathrm{V})\end{array}$ & $\begin{array}{c}\text { Max. } \\
\text { Charge/discharge } \\
\text { current (A) }\end{array}$ \\
\hline 3400 & 3,6 & $2,5-4,2$ & $1,625-5$
\end{tabular}

The battery cell is fully charged with the charger before discharge test. During the discharge test, the battery cell is discharged for 30 seconds, and before the circuit was cut, the circuit voltage and current are measured, and after the circuit was cut, the open circuit voltage is measured. This process is repeated 205 times and each data is recorded.

The maximum discharge state of the battery cell is provided before the charge test. During the charging test, the battery cell is charged for 30 seconds and the circuit voltage and current is measured before the circuit is cut, and the open circuit voltage is measured after the circuit is cut. This process is repeated 437 times and each data is recorded. Using the open circuit voltage $\left(\mathrm{V}_{\mathrm{oc}}\right)$, circuit voltage $\left(\mathrm{V}_{\text {bat }}\right)$ and current $\left(\mathrm{I}_{\mathrm{bat}}\right)$ data obtained by the test method, the internal resistance $(\mathrm{mOhm})$ and efficiency $(\%)$ values of the battery cell is calculated.

\section{Result and discussion}

As a result of the test carried out within the scope of this study, the internal resistance and efficiency are calculated by measuring the circuit voltage, open circuit voltage and current depending on the battery charge rate during the charge and discharge of the battery cell.

Open circuit voltage graph obtained as a result of the test, depending on the battery cell SOC during discharge and charging is shown in Figure 5. The battery open circuit voltage graph obtained is compared with the values in the battery cell data sheet and its accuracy is confirmed.

It has been observed that the battery cell voltage has reached a maximum value of $4.15 \mathrm{~V}$ as a result of the current cut of the charging module. In the discharge test process, it is observed that the open circuit voltage is $3.2 \mathrm{~V}$ when the battery cell charge rate is $7 \%$, and the decrease in the open circuit voltage value is accelerated if it drops below this level. 

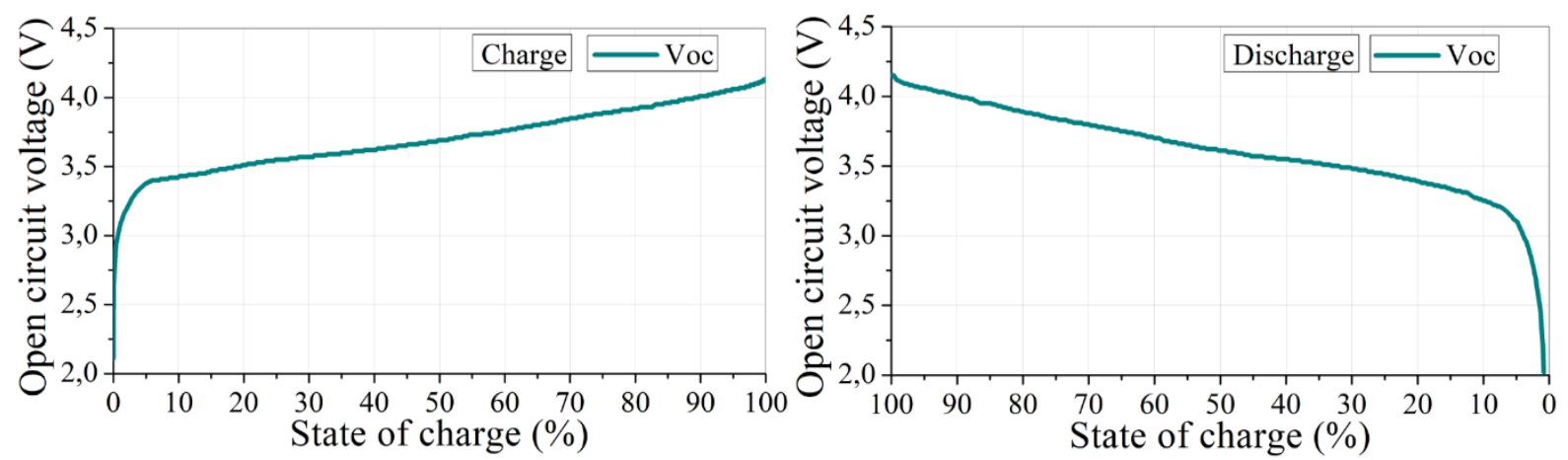

Fig. 5. Open circuit voltage graph based on battery SOC during charging and discharging

The internal resistance graph depending on the battery cell charge rate during battery cell discharge and charging is shown in Figure 6. As a result of the test, it has been observed that the battery cell charge rate starts to rise if it

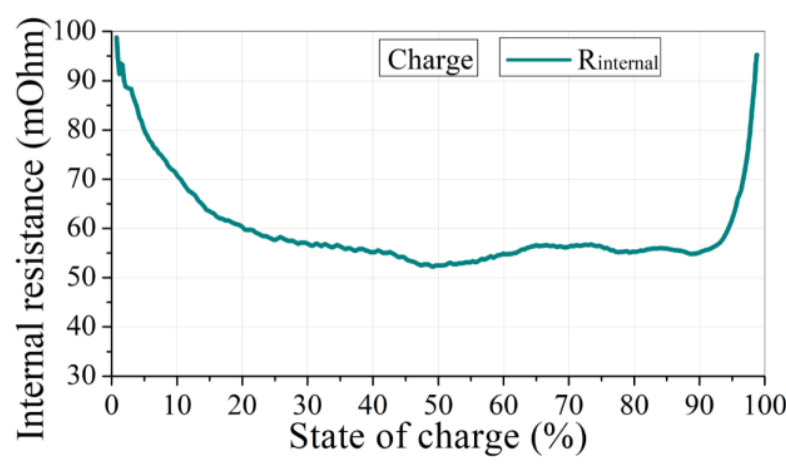

Fig. 6. Internal resistance graph graph based on battery SOC during charging and discharging

The efficiency graph based on the battery cell charge rate during battery cell discharging and charging is created as shown in Figure 7. In case of the battery cell charge rate

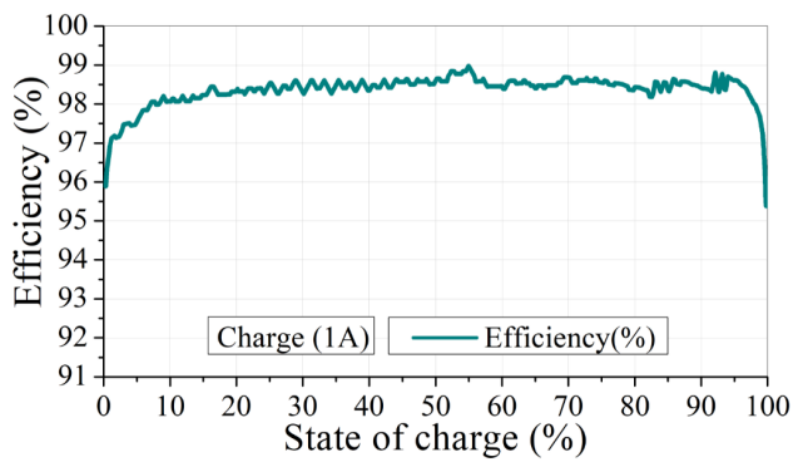

drops below $15 \%$. In case of the battery cell charge rate is between $15 \%$ to $\% 95$, it was determined that the average internal resistance in the discharge process is 51,452 $\mathrm{mOhm}$ and $57,48 \mathrm{mOhm}$ in the charging process.

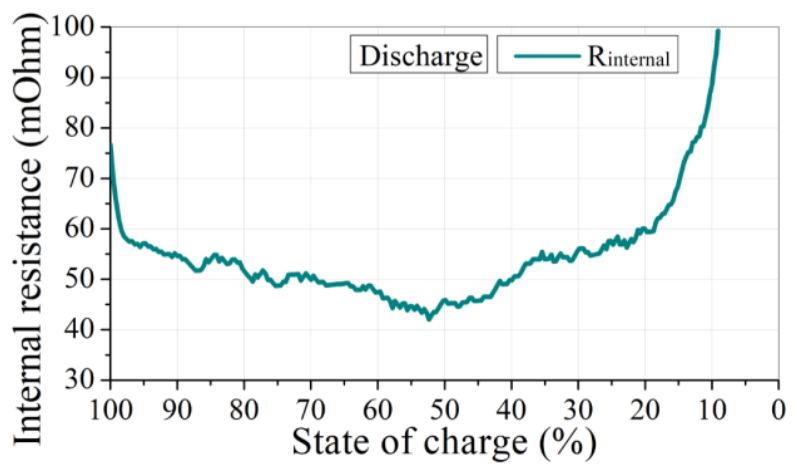

Fig. 7. Efficiency graph graph based on battery SOC during charging and discharging 
[4] Baker, J. (2008). New technology and possible advances in energy storage. Energy Policy, 36.12,4368-4373.

\section{Conclusion}

In this study, the charge and discharge tests of the lithium battery cell used on hybrid vehicles are carried out and the characteristics of the cells are determined by equivalent circuit method the Rint method. As a result of the tests and calculations, it is observed when the battery cell charge rate is between $15 \%$ to $\% 95$, the average internal resistance value is $51,452 \mathrm{mOhm}$ in the discharge process and 57,48 $\mathrm{mOhm}$ in the charging process. In case of the battery cell charge rate is between $15 \%$ to $\% 95$, it is determined that the average efficiency in the discharging process is $98,58 \%$ and $98,496 \%$ in the charging process. The most accurate result in the creation of hybrid and electric vehicle battery models is the equivalent circuit method as can be seen in the related literature. The graphs obtained as a result of the study can be used directly in the modeling of the battery with the equivalent circuit method, Rint method. Open circuit voltage, battery cell internal resistance and efficiency graphs obtained as a result of the study can be provided as an input to battery and battery management system models created for hybrid and electric vehicle models.

\section{Acknowledgements}

Authors thank Osman Safa Danacıŏlu who contributed preparation of the experimental setup.

\section{Nomenclature}

$\begin{array}{ll}\text { Battoten }_{\text {t }} & : \text { battery total energy }(\mathrm{kWh}) \\ \mathrm{I}_{\text {bat }} & : \text { battery current }(\mathrm{A}) \\ \mathrm{Li}-\mathrm{ion} & : \text { lithium ion } \\ \mathrm{NiMH} & : \text { Nikel metal hidrat } \\ \mathrm{P}_{\text {bat }} & : \text { battery power }(\mathrm{W}) \\ \mathrm{PNGV} & : \text { partnership for a new generation of vehicles } \\ \mathrm{RC} & : \text { resistor-capacitor } \\ \mathrm{R}_{\text {internal }} & : \text { internal resistance }(\mathrm{mOhm}) \\ \mathrm{SOC} & : \text { State of charge } \\ \mathrm{V}_{\text {bat }} & : \text { battery voltage }(\mathrm{V}) \\ \mathrm{V}_{\mathrm{oc}} & : \text { open circuit voltage }(\mathrm{V})\end{array}$

\section{Refenrances}

[1] Li, X., Dai, K., Wang, Z., \& Han, W. (2020). Lithium-ion batteries fault diagnostic for electric vehicles using sample entropy analysis method. Journal of Energy Storage, 27, 101121.

[2] Keskin, A. (2009). Hybrid vehicle technologies and applications. Engineer \& the Machinery Magazine, 597, 12-20.

[3] Gao, Y., Yin, L., Kim, S. J., Yang, H., Jeon, I., Kim, J. P., \& Cho, C. R. (2019). Enhanced lithium storage by ZnFe2O4 nanofibers as anode materials for lithium-ion battery. Electrochimica Acta, 296, 565-574.
[5] Ruiz, V., Pfrang, A., Kriston, A., Omar, N., Van den Bossche, P., \& Boon-Brett, L. (2018). A review of international abuse testing standards and regulations for lithium ion batteries in electric and hybrid electric vehicles. Renewable and Sustainable Energy Reviews, 81, 1427-1452.

[6] Zhang, Q., Cui, N., Li, Y., Duan, B., \& Zhang, C. (2020). Fractional calculus based modeling of open circuit voltage of lithium-ion batteries for electric vehicles. Journal of Energy Storage, 27, 100945.

[7] Marques, P., Garcia, R., Kulay, L., \& Freire, F. (2019). Comparative life cycle assessment of lithium-ion batteries for electric vehicles addressing capacity fade. Journal of Cleaner Production, 229, 787-794.

[8] Yong, J. Y., Ramachandaramurthy, V. K., Tan, K. M., \& Mithulananthan, N. (2015). A review on the state-of-the-art technologies of electric vehicle, its impacts and prospects. Renewable and Sustainable Energy Reviews, 49, 365-385.

[9] Solmaz, H, Kocakulak, T. Modelling of a serial hybrid vehicle with HCCI range extender engine. Gazi University Journal of Science and Technology Part C: Design and Technology, 8(2), 279-292.

[10] Hannan, M. A., Lipu, M. H., Hussain, A., Mohamed, A. (2017). A review of lithium-ion battery state of charge estimation and management system in electric vehicle applications: Challenges and recommendations. Renewable and Sustainable Energy Reviews, 78, 834-854.

[11] Muratoğlu, Y., Alkaya, A. (2015). Electric vehicle technology and battery management system-review. VIII. Renewable Energy Resources Symposium. pp.243-248.

[12] Banguero, E., Correcher, A., Pérez-Navarro, Á., Morant, F., \& Aristizabal, A. (2018). A review on battery charging and discharging control strategies: Application to renewable energy systems. Energies, 11(4), 1021.

[13] Kunt, M. A. Advisor based modelling of regenerative braking performance of electric vehicles at different road slopes. International Journal of Automotive Science and Technology, 4(2), 98-104.

[14] Erdinç, O., Uzunoğlu, M. and Vural, B. (2011). Energy storage units used in hybrid alternative energy systems. Electric-Electronic and Computer Symposium, Elazığ, 116-126.

[15] Chen, W., Liang, J., Yang, Z., \& Li, G. (2019). A review of lithium-ion battery for electric vehicle applications and beyond. Energy Procedia, 158, 4363-4368.

[16] 16. Potrykus, S., Kutt, F., Nieznański, J., \& Morales, F. J. F. (2020). Advanced lithium-ion battery model for power system performance analysis. Energies, 13(10), 2411.

[17] Yenigün, M. and Utlu, Z. (2018). Examination and evaluation of battery cooling systems used in electric vehicles. Engineer \& the Machinery Magazine. 59(692), 35-47.

[18] Jilte, R. D., Kumar, R., Ahmadi, M. H., \& Chen, L. (2019). Battery thermal management system employing phase 
change material with cell-to-cell air cooling. Applied Thermal Engineering, 161, 114199.

[19] Wu, W., Wang, S., Wu, W., Chen, K., Hong, S., \& Lai, Y. (2019). A critical review of battery thermal performance and liquid based battery thermal management. Energy conversion and management, 182, 262-281.

[20] Ceylan, M., Sarıkurt, T. and Balıkçı, A. (2013). Model development for lithium-ion batteries used in electric vehicles. 5th Energy Efficiency and Quality Congress. 23-24.

[21] Tremblay, O., Dessaint, L. A., Dekkiche, A. I. (2007). A generic battery model for the dynamic simulation of hybrid electric vehicles. IEEE Vehicle Power and Propulsion Conference. 284-289.

[22] Samadani, E., Farhad, S., Panchal, S., Fraser, R., Fowler, M. (2014). Modeling and evaluation of li-Ion battery performance based on the electric vehicle field tests. SAE Technical Paper, 1848, 8-16.

[23] Rao, R., Vrudhula, S., Rakhmatov, D. N. (2003). Battery modeling for energy aware system design. Computer, 36.12, 77-87.

[24] Tezde, E. İ. and Okumuş, H. İ. (2018). Battery models and state of charge (SOC) determination. EMO Scientific Journal, 8(1), 21-25.

[25] Lin, Q., Wang, J., Xiong, R., Shen, W., \& He, H. (2019). Towards a smarter battery management system: A critical review on optimal charging methods of lithium ion batteries. Energy, 183, 220-234.

[26] Sezer, V. (2008). Modeling and optimal power management of a parallel hybrid electric vehicle. PhD Thesis, Istanbul Technical University.

[27] Stroe, D. I., Zaharof, A. and Iov, F. (2018). Power and energy management with battery storage for a ybrid residential pv-wind system-a case study for Denmark. Energy Procedia, 155, 464-477.

[28] Panasonic Corporation (2012), NCR18650B Standard data. Web: https://enerpower.de/wp/wp-content/uploads/2016/03/Specification_NCR18650B.pdf, last access date: 09.07.2020 